Marquette University

e-Publications@Marquette

Biological Sciences Faculty Research and

Publications

Biological Sciences, Department of

9-1-2009

\title{
Fatty Acid Oxidation and Meiotic Resumption in Mouse Oocytes
}

Stephen Downs

Marquette University, stephen.downs@marquette.edu

Jessica Odette

Marquette University

John Klinger

Marquette University

Accepted version. Molecular Reproduction and Development, Vol. 76, No. 9 (September 2009): 844-853. DOI. (C) 2009 Wiley. Used with permission.

This article may be used for non-commercial purposes in accordance With Wiley Terms and Conditions for self-archiving. 


\title{
Fatty Acid Oxidation and Meiotic Resumption in Mouse Oocytes
}

\author{
Stephen M. Downs \\ Department of Biological Sciences, Marquette University \\ Milwaukee, Wisconsin \\ Jessica Odette \\ Department of Biological Sciences, Marquette University \\ Milwaukee, Wisconsin \\ John Klinger \\ Department of Biological Sciences, Marquette University \\ Milwaukee, Wisconsin
}

\begin{abstract}
:
We have examined the potential role of fatty acid oxidation (FAO) in AMP-activated protein kinase (AMPK)-induced meiotic maturation. Etomoxir and malonyl CoA, two inhibitors of carnitine palmitoyl transferase-1 (CPT1), and thus FAO, blocked meiotic induction in dbcAMP-arrested cumulus cellenclosed oocytes (CEO) and denuded oocytes (DO) by the AMPK activator, AICAR. C75, an activator of CPT1 and FAO, stimulated meiotic resumption in CEO and DO. This effect was insensitive to the AMPK inhibitor, compound C, indicating an action downstream of AMPK. Palmitic acid or carnitine also promoted meiotic resumption in DO in the presence of AICAR. Since C75 also suppresses the activity of fatty acid synthase (FAS), we tested another FAS inhibitor, cerulenin. Cerulenin stimulated maturation in arrested oocytes, but to a lesser extent, exhibited significantly slower kinetics and was effective in
\end{abstract}

Molecular Reproduction and development, Vol. 76, No. 9 (September 2009): pg. 844-853. DOI. This article is (c) Wiley and permission has been granted for this version to appear in e-Publications@Marquette. Wiley does not grant permission for this article to be further copied/distributed or hosted elsewhere without the express permission from Wiley. 
NOT THE PUBLISHED VERSION; this is the author's final, peer-reviewed manuscript. The published version may be accessed by following the link in the citation at the bottom of the page.

CEO but not DO. Moreover, etomoxir completely blocked C75-induced maturation but was ineffective in cerulenin-treated oocytes, suggesting that the meiosis-inducing action of C75 is through activation of FAO within the oocyte, while that of cerulenin is independent of FAO and acts within the cumulus cells. Finally, we determined that long chain, but not short chain, fatty acyl carnitine derivatives were stimulatory to oocyte maturation. Palmitoyl carnitine stimulated maturation in both CEO and DO, with rapid kinetics in DO; this effect was blocked by mercaptoacetate, a downstream inhibitor of FAO. These results indicate that activation of AMPK stimulates meiotic resumption in mouse oocytes by eliminating a block to FAO.

Keywords: fatty acid oxidation, oocyte maturation, AMPK.

\section{Introduction}

Oocyte maturation in mammals is a carefully regulated process critically dependent on the interaction of the germ and somatic compartments of the ovarian follicle. Once meiotic competence is achieved in the developing oocyte, the granulosa cells serve to sustain a prophase I arrest until the appropriate hormonal signal triggers meiotic resumption. This is exemplified by the spontaneous meiotic resumption that occurs when oocytes from Graafian follicles are isolated and cultured in vitro in the absence of inhibitory follicular components. The stimulatory signal for meiotic resumption in vivo originates in the granulosa cells in response to gonadotropin binding at the time of the mid-cycle hormonal surge and is transmitted to the oocyte where it induces germinal vesicle breakdown (GVB). Recent studies indicate that meiotic maturation in vivo requires the release of EGF-like peptides from the somatic compartment that act in a paracrine/autocrine fashion on the cumulus granulosa cells to generate such a stimulus (Conti et al, 2006; Downs and Chen, 2008)). The downstream meiosis-inducing signal that results from stimulation by gonadotropin and EGF-like peptides is unknown and remains a challenging area of research.

We have recently presented evidence that AMP-activated protein kinase (AMPK) is present in mouse oocytes and that, when activated, can stimulate GVB in meiotically arrested oocytes in vitro (Downs et al, 2002; Chen et al, 2006). AMPK is an important regulatory enzyme that helps maintain energy homeostasis in cells such that when energy levels are low, AMPK shuts down energy-depleting pathways and turns

Molecular Reproduction and development, Vol. 76, No. 9 (September 2009): pg. 844-853. DOI. This article is @ Wiley and permission has been granted for this version to appear in e-Publications@Marquette. Wiley does not grant permission for this article to be further copied/distributed or hosted elsewhere without the express permission from Wiley. 
on energy-generating pathways (Hardie, 2003). An important substrate of AMPK is acetyl CoA carboxylase (ACC; Davies et al, 1992), a rate-limiting enzyme in fatty acid synthesis that generates malonyl CoA from acetyl CoA (see Fig. 1). AMPK phosphorylates, and thereby inactivates, ACC, leading to a decrease in malonyl CoA levels (Tong, 2005). AMPK has also been reported to stimulate the activity of malonyl CoA decarboxylase, which catalyzes the reverse reaction, the decarboxylation of malonyl CoA to acetyl CoA (Park et al, 2002a). Malonyl CoA is the first intermediate of lipogenesis and is an important negative regulator of carnitine palmitoyltransferase I (CPT1;

Ruderman et al, 2003; Wolfgang and Lane, 2006), the enzyme located on the outer mitochondrial membrane that catalyzes the replacement of the acyl CoA group of large chain fatty acids with carnitine. This addition of carnitine promotes fatty acid entry into mitochondria and is the rate-limiting step for the $\beta$-oxidation of long-chain fatty acids (McGarry and Brown, 1997). Hence, malonyl CoA is an important negative regulator of fatty acid oxidation, and one of the significant consequences of AMPK activation in cells is stimulation of fatty acid oxidation by virtue of a decrease in malonyl CoA levels and subsequent removal of the block to this metabolic pathway (Ruderman et al, 2003).

Molecular Reproduction and development, Vol. 76, No. 9 (September 2009): pg. 844-853. DOI. This article is (C Wiley and permission has been granted for this version to appear in e-Publications@Marquette. Wiley does not grant permission for this article to be further copied/distributed or hosted elsewhere without the express permission from Wiley. 
NOT THE PUBLISHED VERSION; this is the author's final, peer-reviewed manuscript. The published version may be accessed by following the link in the citation at the bottom of the page.

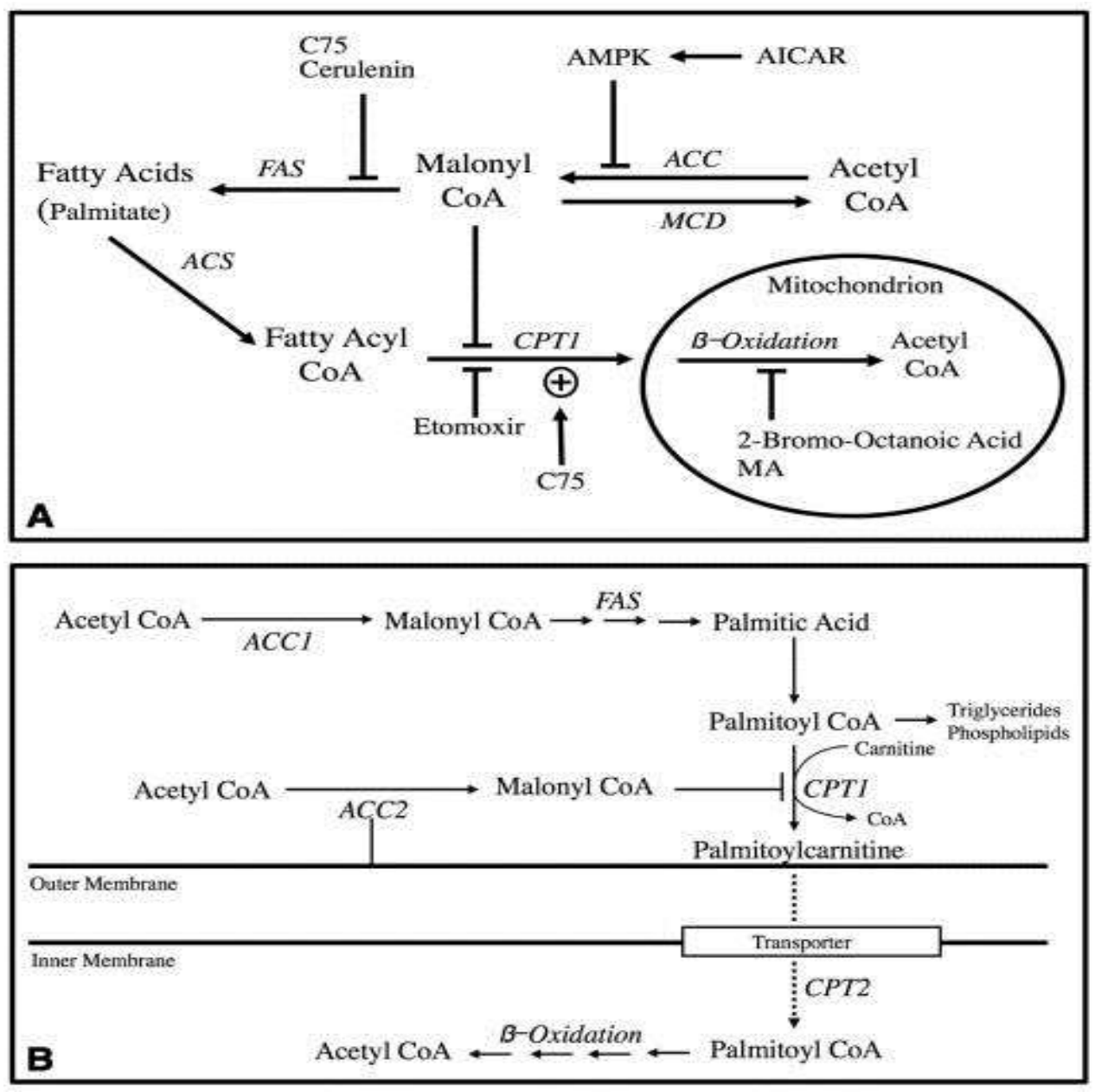

Figure 1 Flow diagrams of fatty acid metabolism. A, Modulation of fatty acid metabolism by different molecules. AMPK, stimulated by AICAR, phosphorylates and inactivates acetyl CoA carboxylase (ACC), thereby lowering malonyl CoA levels. Malonyl CoA and etomoxir are negative regulators of carnitine palmitoyltransferase- 1 (CPT1) and restrict fatty acid entry into mitochondria, thereby blocking fatty acid oxidation. C75 has an opposite, positive effect on CPT1 and promotes fatty acid entry and $\beta$-oxidation. C75 also suppresses fatty acid synthase (FAS) activity and thereby reduces fatty acid synthesis, an effect mimicked by cerulenin. MCD, malonyl CoA decarboxylase. B, Regulation of fatty acid entry into mitochondria. Fatty acids are transported into the mitochondria following replacement of the CoA moiety with carnitine through the action of CPT1. This action is blocked by malonyl CoA that is produced by ACC1, which is associated with the outer membrane of the mitochondrion. Oxidation occurs after the carnitine is replaced with CoA by the action of CPT2. Cytoplasmic ACC1 produces the malonyl CoA that serves as precursor for fatty acid synthesis. Figure B is adapted from Tong, 2005.

ACC is an important substrate of AMPK (Carling et al, 1989; Davies et al, 1992; Park et al, 2002b) and its phosphorylation state serves as an effective indirect assay for AMPK activation. We have 
shown by western analysis that ACC phosphorylation in mouse oocytes is associated with AMPK activation and meiotic resumption (Chen et al, 2006, 2008; LaRosa and Downs, 2006, 2007). It follows that suppression of ACC activity in mouse oocytes by AMPK would lower malonyl CoA levels and relieve its inhibitory influence on fatty acid oxidation. ATP generated by oxidation of fatty acids could subsequently serve important energy needs as well as provide phosphate for kinase reactions within signal transduction pathways involved in meiotic induction. The present study was therefore carried out to test the possible involvement of fatty acid oxidation in meiotic resumption in mouse oocytes, and data presented herein support the idea that fatty acid oxidation is an essential downstream regulatory pathway participating in AMPK-induced meiotic induction.

\section{RESULTS}

\section{CPT1 inhibitors block AICAR-induced meiotic maturation}

Initial experiments tested the effect of inhibitors of CPT1 on AICAR-induced meiotic resumption in dbcAMP-arrested denuded oocytes (DO). DO were cultured $4 \mathrm{~h}$ in medium containing $300 \mu \mathrm{m}$ dbcAMP, to which was added $250 \mu \mathrm{M}$ AICAR plus increasing concentrations of one of two inhibitors, etomoxir or malonyl CoA. Etomoxir is a pharmacological inhibitor of carnitine palmitoyl transferase I (CPT1; Declercq et al, 1987), while malonyl CoA, as an intermediate in the fatty acid synthetic pathway, is a physiological inhibitor of CPT1 (Ruderman et al, 2002; see Fig. 1). Blocking CPT1 activity prevents entry of large chain fatty acids into mitochondria and their $\beta$-oxidation. AICAR stimulated oocyte maturation by $42-51 \%$, and this meiotic induction was completely suppressed in dosedependent fashion by either etomoxir (Fig. 2A) or malonyl CoA (Fig. 2B).

Molecular Reproduction and development, Vol. 76, No. 9 (September 2009): pg. 844-853. DOI. This article is @ Wiley and permission has been granted for this version to appear in e-Publications@Marquette. Wiley does not grant permission for this article to be further copied/distributed or hosted elsewhere without the express permission from Wiley. 

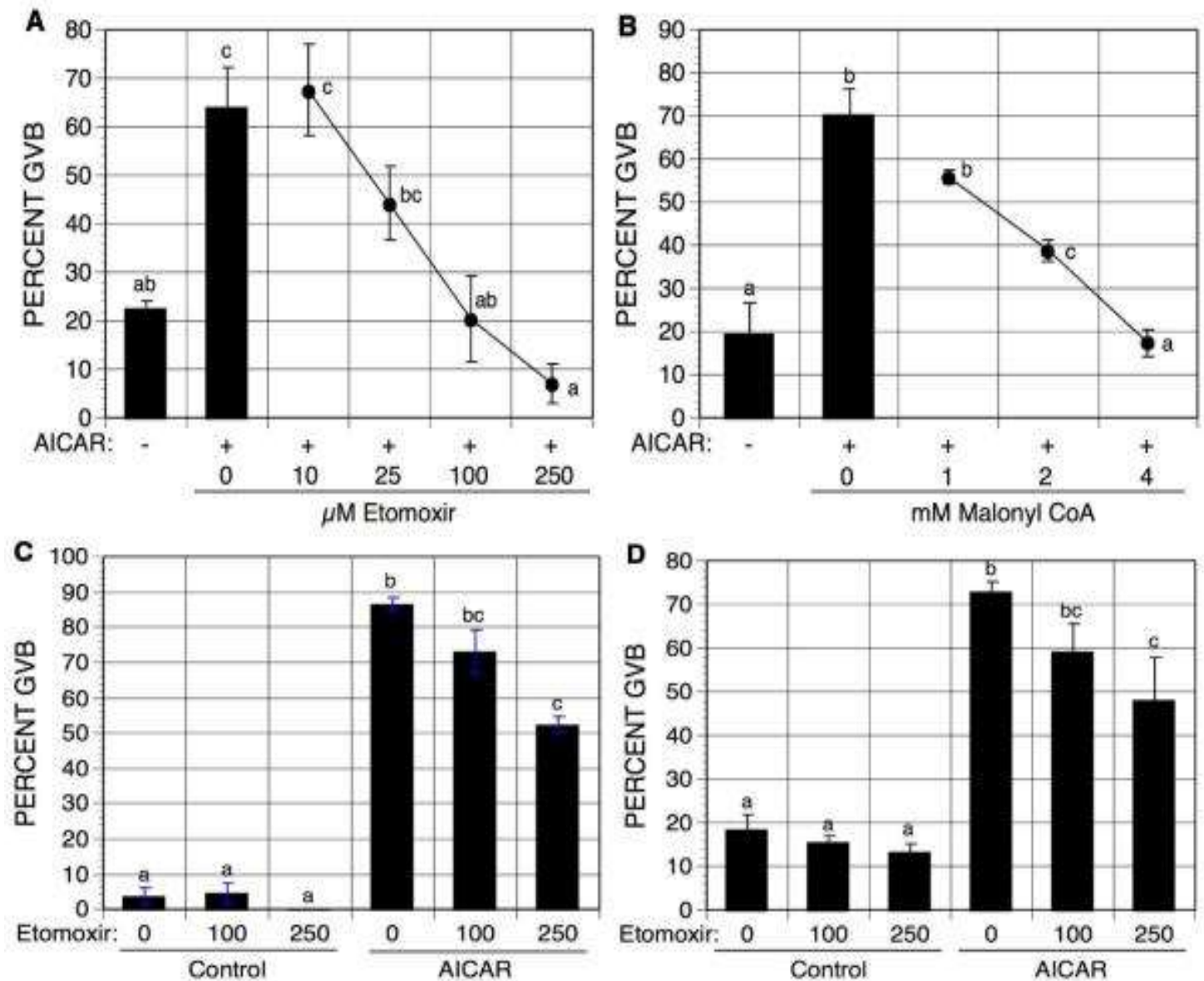

Figure 2 Inhibition of meiotic induction by etomoxir and malonyl CoA. Denuded oocytes were maintained in meiotic arrest with $3000 \mu \mathrm{M}$ dbcAMP and were stimulated to resume maturation with $250 \mu \mathrm{M}$ AICAR. Etomoxir (A) or malonyl CoA (B) was added in increasing concentrations and GVB was assessed $4 \mathrm{~h}$ later. The effects of etomoxir were then tested under similar conditions but with meiotic arrest maintained with milrinone (C) or hypoxanthine (D). Groups with no common letter are significantly different.

We next tested the effects of etomoxir on AICAR-stimulated maturation when DO were maintained in meiotic arrest with two different inhibitors: hypoxanthine or the phosphodiesterase $3 \mathrm{~A}$ inhibitor, milrinone. In the hypoxanthine-treated groups, AICAR increased the maturation percentage from 18.5 to $73.1 \%$. Etomoxir did not significantly alter AICAR-induced maturation at $100 \mu \mathrm{M}$, but at a dose of $250 \mu \mathrm{M}$ reduced meiotic induction by $25 \%$ (Fig. 2C). In milrinone-treated DO, AICAR increased the maturation frequency from $3.8 \%$ to $86.6 \%$, and the effects of etomoxir were essentially identical, with a $33.7 \%$ reduction in GVB at the higher dose of $250 \mu \mathrm{M}$ (Fig. 2D). In either inhibitory condition, etomoxir had no effect in the absence of AICAR. 
To determine if etomoxir or malonyl CoA have an inhibitory effect on non-stimulated oocytes, DO were cultured $3 \mathrm{~h}$ in inhibitorfree control medium or medium containing $100 \mu \mathrm{M}$ dbcAMP, plus either $250 \mu \mathrm{M}$ etomoxir or $4 \mathrm{mM}$ malonyl CoA. In the absence of dbcAMP, $95 \%$ of the oocytes underwent GVB, and neither etomoxir nor malonyl CoA had an inhibitory effect. In the presence of dbcAMP, $89 \%$ of oocytes had resumed maturation, and maturation was completely suppressed by the higher dose of etomoxir, with a nominal reduction in the presence of malonyl CoA (69\% GVB; Fig. 3). When these etomoxir-treated oocytes were washed and placed in control, inhibitorfree medium overnight, $100 \%$ resumed maturation and over $90 \%$ extruded a polar body, demonstrating that etomoxir had no permanent toxic effect. When DO were cultured $2 \mathrm{~h}$ in dbcAMP plus etomoxir, washed and cultured an additional $3 \mathrm{~h}$ in etomoxir alone, more than $95 \%$ of the oocytes resumed maturation (data not shown), suggesting that the lack of effect in spontaneously maturing oocytes was not due to meiotic commitment before assimilation of etomoxir by the oocyte.

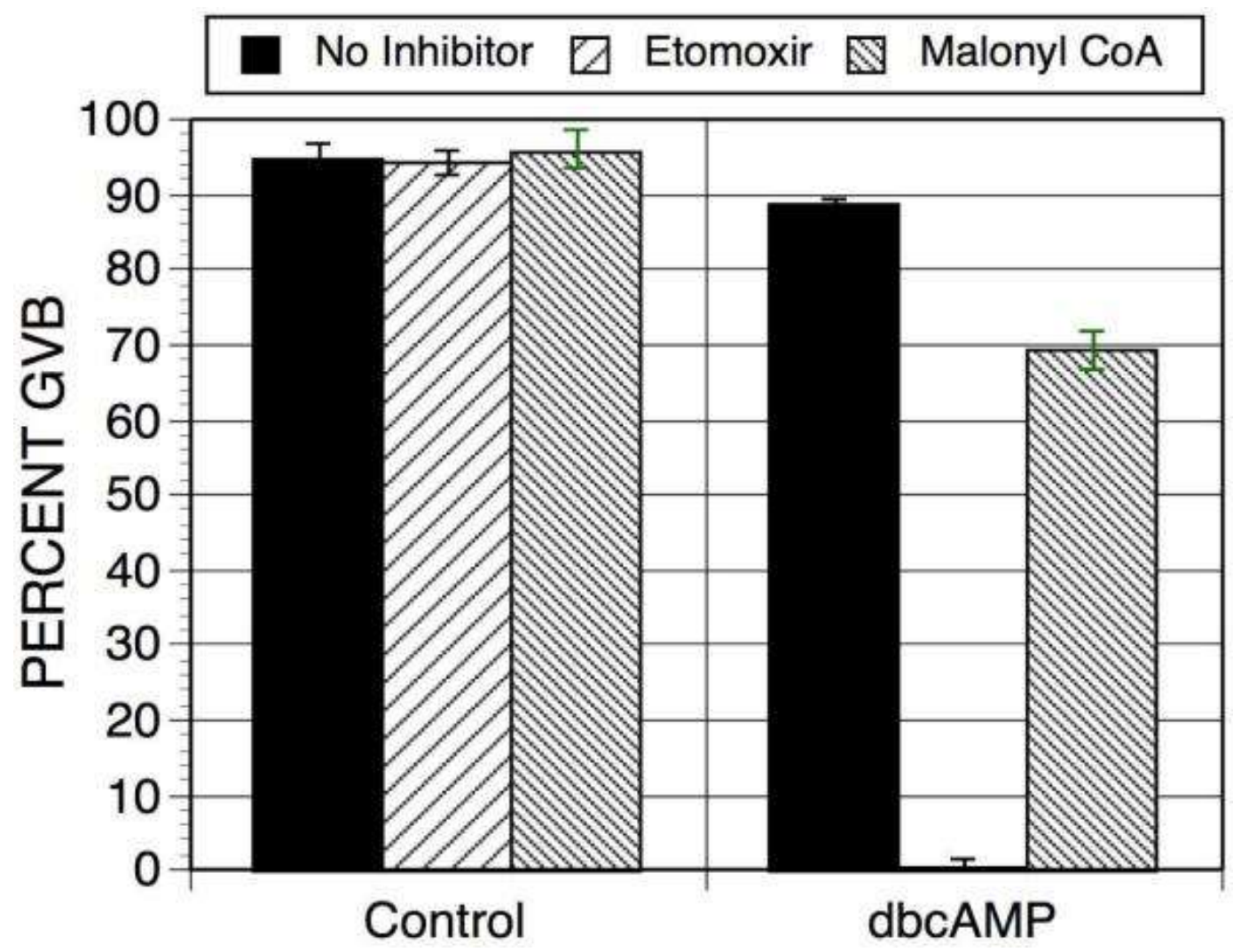

Molecular Reproduction and development, Vol. 76, No. 9 (September 2009): pg. 844-853. DOI. This article is (C Wiley and permission has been granted for this version to appear in e-Publications@Marquette. Wiley does not grant permission for this article to be further copied/distributed or hosted elsewhere without the express permission from Wiley. 
Figure 3 Effect of etomoxir and malonyl CoA on nonstimulated oocytes. Denuded oocytes were cultured $3 \mathrm{~h}$ in control medium or in medium supplemented with $100 \mu \mathrm{M}$ dbcAMP, in the presence or absence of $250 \mu \mathrm{M}$ etomoxir or $4 \mathrm{mM}$ malonyl CoA, and then assessed for GVB.

To examine the possibility that etomoxir has a general toxic effect that interferes with normal meiotic regulation, the effects of this inhibitor were tested on FSH-stimulated cumulus expansion. These results are shown in Table 1 . When cultured in medium supplemented with $300 \mu \mathrm{m}$ dbcAMP, negligible cumulus expansion occurred, with a cumulus expansion index of only 0.08 (range $0-4.0$ ); similar results were obtained with the addition of either 100 or $250 \mu \mathrm{M}$ etomoxir. FSH stimulated nearly complete expansion, with a CEI of 3.65, and this response was unaffected by etomoxir at either dose, demonstrating that the inhibitor has selective effects on the oocyte-cumulus cell complex.

\begin{tabular}{|c|c|c|c|c|c|c|c|}
\hline Treatment ${ }^{*}$ & $\mathbf{n}$ & 0 & +1 & +2 & +3 & +4 & CEI \\
\hline Control & 77 & 72 & 5 & 0 & 0 & 0 & 0.06 \\
\hline $100 \mu \mathrm{M}$ Etomoxir & 54 & 51 & 3 & 0 & 0 & 0 & 0.06 \\
\hline $250 \mu \mathrm{M}$ Etomoxir & 59 & 56 & 3 & 0 & 0 & 0 & 0.05 \\
\hline FSH & 77 & 0 & 0 & 8 & 25 & 44 & 3.46 \\
\hline $\mathrm{FSH}+100 \mu \mathrm{M}$ Etomoxir & 86 & 0 & 0 & 3 & 16 & 67 & 3.74 \\
\hline $\mathrm{FSH}+250 \mu \mathrm{M}$ Etomoxir & 89 & 0 & 0 & 8 & 15 & 66 & 3.82 \\
\hline
\end{tabular}

\section{TABLE 1 Effects of Etomoxir on cumulus expansion}

${ }^{*}$ Complexes were cultured $17-18 \mathrm{~h}$ in medium containing $300 \mu \mathrm{M}$ dbcAMP. At the conclusion of culture, expansion was assessed on a subjective scale from 0-4 and a cumulus expansion index (CEI) for the pooled data was calculated. Data are pooled from 2-3 experiments. 


\section{An activator of CPT1 stimulates meiotic resumption in etomoxir-sensitive fashion}

Since results of these experiments suggested a mediating role for fatty acid oxidation in meiotic induction, C75, an activator of CPT1 and, thus, fatty acid oxidation (Thupari et al, 2002; Landree et al, 2004; Yang et al, 2005), was next tested on meiotically arrested DO and CEO. Oocytes were cultured $17-18 \mathrm{~h}$ in medium containing 300 $\mu \mathrm{m}$ dbcAMP plus increasing concentrations of C75. As shown in Fig. $4 \mathrm{~A}$, this agent stimulated the maturation of $\mathrm{DO}$ and CEO in dosedependent fashion, with more effective meiotic induction in CEO at the lower doses. Essentially all DO and CEO resumed maturation at the highest dose tested $(100 \mu \mathrm{M})$.
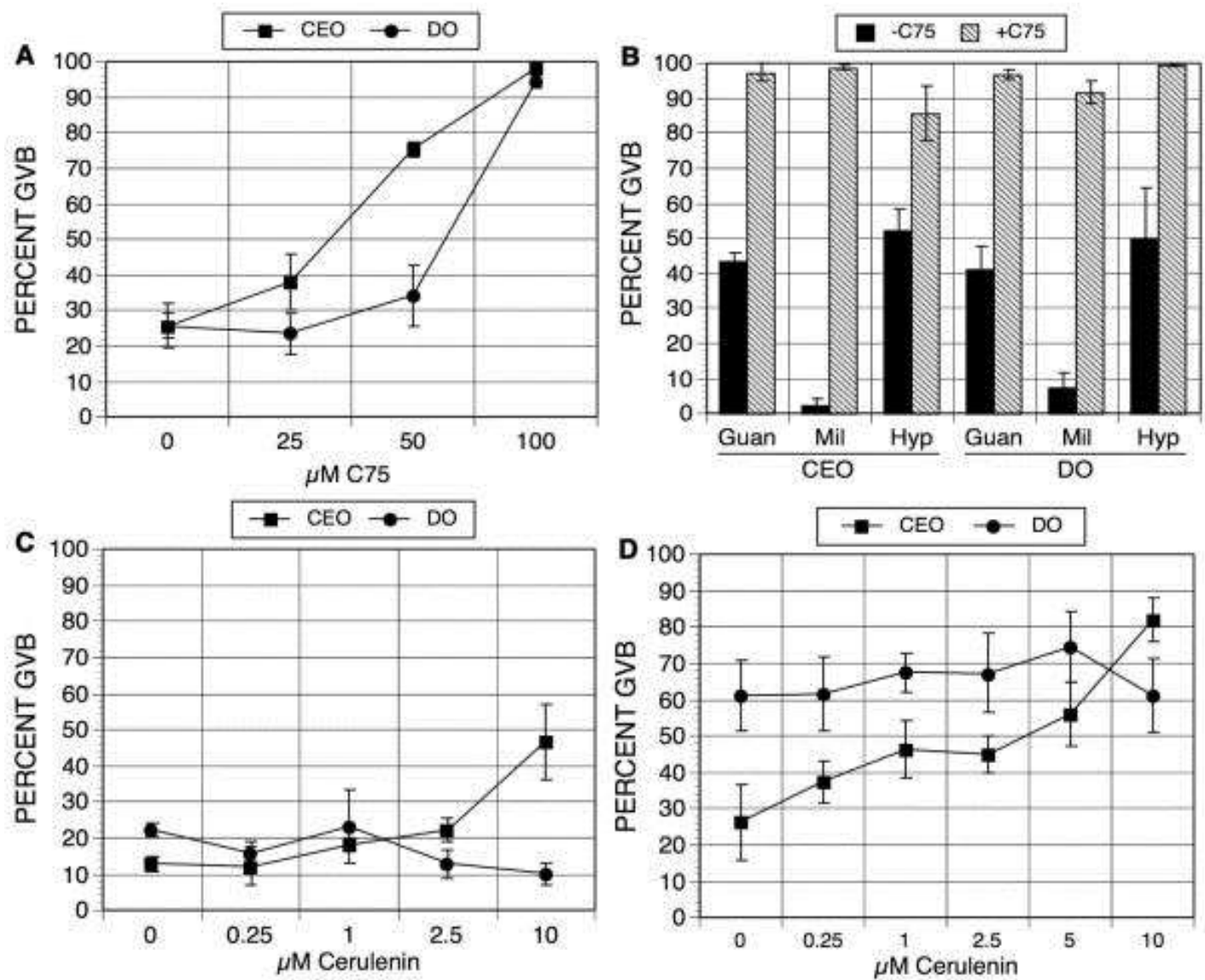

Figure 4 Effect of $C 75$ and cerulenin on meiotic maturation. A, CEO and DO were cultured $17-18 \mathrm{~h}$ in medium containing $300 \mu \mathrm{M}$ dbcAMP plus increasing concentrations of C75. B, CEO or DO were cultured 17-18 h in medium containing $1 \mathrm{mM}$ guanosine (Guan), $2 \mu \mathrm{M}$ milrinone (Mil) or $4 \mathrm{mM}$ hypoxanthine (Hyp), in the presence or absence of $100 \mu \mathrm{M}$ C75. In all groups, C75 stimulated a significant increase in GVB. CEO and

Molecular Reproduction and development, Vol. 76, No. 9 (September 2009): pg. 844-853. DOI. This article is (C Wiley and permission has been granted for this version to appear in e-Publications@Marquette. Wiley does not grant permission for this article to be further copied/distributed or hosted elsewhere without the express permission from Wiley. 
NOT THE PUBLISHED VERSION; this is the author's final, peer-reviewed manuscript. The published version may be accessed by following the link in the citation at the bottom of the page.

DO were cultured $17-18 \mathrm{~h}$ in medium containing $300 \mu \mathrm{M}$ dbcAMP (C) or $4 \mathrm{mM}$ hypoxanthine $(D)$ plus increasing concentrations of cerulenin. Cerulenin had no effect on DO but did stimulate maturation in CEO.

To assess whether this was a general effect of C75, the agent was tested on three additional meiotic inhibitors--guanosine, milrinone and hypoxanthine--during overnight culture. For each treatment group, significant stimulation of GVB by $C 75$ was achieved in both DO and CEO (Fig. 4B), indicating the C75 effect was not dependent upon the type of inhibitor used to maintain meiotic arrest.

Because C75 can also act to prevent fatty acid synthesis (Kuhajda et al, 2000; Loftus et al, 2000), we tested whether another inhibitor of fatty acid synthesis, cerulenin (Omura, 1976; Kawaguchi et al, 1982; Loftus et al, 2000), could stimulate maturation in dbcAMParrested oocytes. While cerulenin had no effect on DO, meiotic resumption was stimulated in CEO in dose-dependent fashion, with the highest dose, $10 \mu \mathrm{M}$, increasing the maturation percentage by $33.9 \%$, from $12.8 \%$ to $46.9 \%$ GVB (Fig. $5 \mathrm{~A}$ ). This was the maximum induction, because higher doses proved toxic. When the experiment was repeated in hypoxanthine-supplemented medium, cerulenin again produced a dose-dependent stimulation of maturation in CEO, with the percent GVB increasing from $26 \%$ to $82 \%$ at $10 \mu \mathrm{M}$ (Fig. 5B).

Consistent with previous studies, hypoxanthine was a weaker inhibitor than dbcAMP in DO, with $56 \%$ of the oocytes resuming maturation. Despite this limited potency of hypoxanthine, cerulenin again failed to induce maturation in DO

Molecular Reproduction and development, Vol. 76, No. 9 (September 2009): pg. 844-853. DOI. This article is (C Wiley and permission has been granted for this version to appear in e-Publications@Marquette. Wiley does not grant permission for this article to be further copied/distributed or hosted elsewhere without the express permission from Wiley. 
NOT THE PUBLISHED VERSION; this is the author's final, peer-reviewed manuscript. The published version may be accessed by following the link in the citation at the bottom of the page.
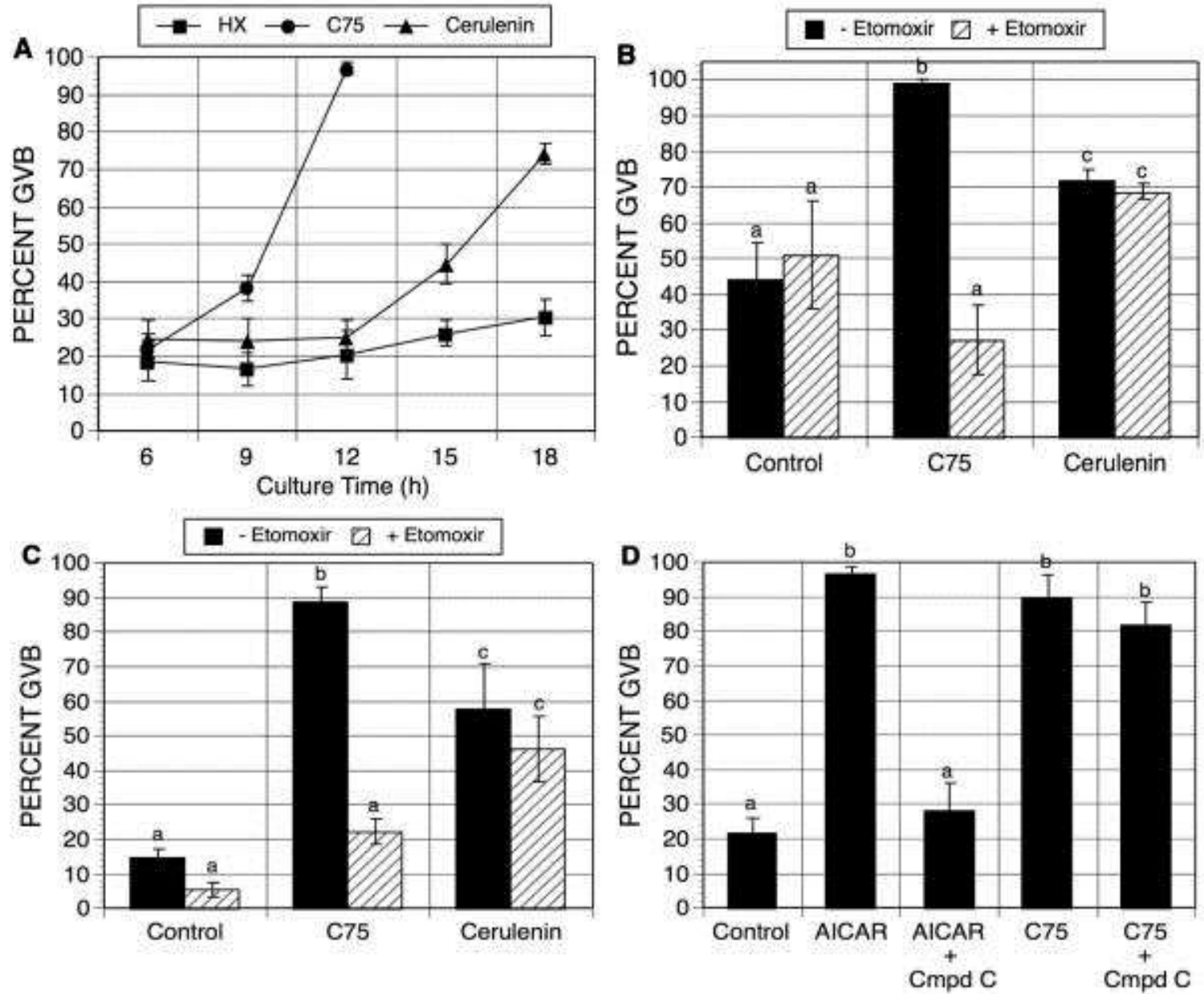

Figure 5 Comparative actions of $\mathrm{C} 75$ and cerulenin on oocyte maturation. A, Kinetics of meiotic induction. CEO were cultured in $4 \mathrm{mM}$ hypoxanthine, plus or minus $100 \mu \mathrm{M}$ C75 or $10 \mu \mathrm{M}$ cerulenin, and GVB was assessed after varying culture times.

$\mathrm{B}, \mathrm{C}$, Effects of etomoxir on meiotic induction by $\mathrm{C} 75$ and cerulenin. CEO were cultured $18 \mathrm{~h}$ in $300 \mu \mathrm{M}$ dbcAMP (B) or $4 \mathrm{mM}$ hypoxanthine (C) and stimulated to undergo maturation with $100 \mu \mathrm{M} \mathrm{C75}$ or $10 \mu \mathrm{M}$ cerulenin. Etomoxir was administered at a concentration of $100 \mu \mathrm{M}$ in dbcAMP-supplemented medium and $250 \mu \mathrm{M}$ in hypoxanthine-supplemented medium. D, CEO were cultured $17-18 \mathrm{~h}$ in medium containing dbcAMP and stimulated to undergo maturation with $250 \mu \mathrm{M}$ AICAR or 100 $\mu \mathrm{M}$ C75. They were treated with $2.5 \mu \mathrm{M}$ compound $\mathrm{C}$ and $17-18 \mathrm{~h}$ later assessed for GVB. Groups with no common letter are significantly different.

Since a pronounced meiosis-inducing effect was observed in CEO following either C75 or cerulenin treatment, we compared the kinetics of meiotic resumption in hypoxanthine-arrested CEO exposed

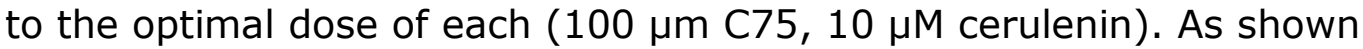
in Fig. 6, meiotic resumption occurred at a much faster rate in $\mathrm{C} 75-$ treated CEO, as induction was initiated between 6 and $9 \mathrm{~h}$ of culture,

Molecular Reproduction and development, Vol. 76, No. 9 (September 2009): pg. 844-853. DOI. This article is (C) Wiley and permission has been granted for this version to appear in e-Publications@Marquette. Wiley does not grant permission for this article to be further copied/distributed or hosted elsewhere without the express permission from Wiley. 
and complete induction (96.9\% GVB compared to $20.4 \%$ in controls) was observed by $12 \mathrm{~h}$ of culture. On the other hand, no stimulation of GVB by cerulenin had occurred after $12 \mathrm{~h}$; rather, meiotic induction required at least $15 \mathrm{~h}$ of culture time and, by $18 \mathrm{~h}$, the maturation percentage had reached only $74.1 \%$ compared to $30.5 \%$ in controls. Thus, the kinetics of meiotic induction were considerably slower, the extent of induction was lower, and only CEO responded in cerulenintreated oocytes.
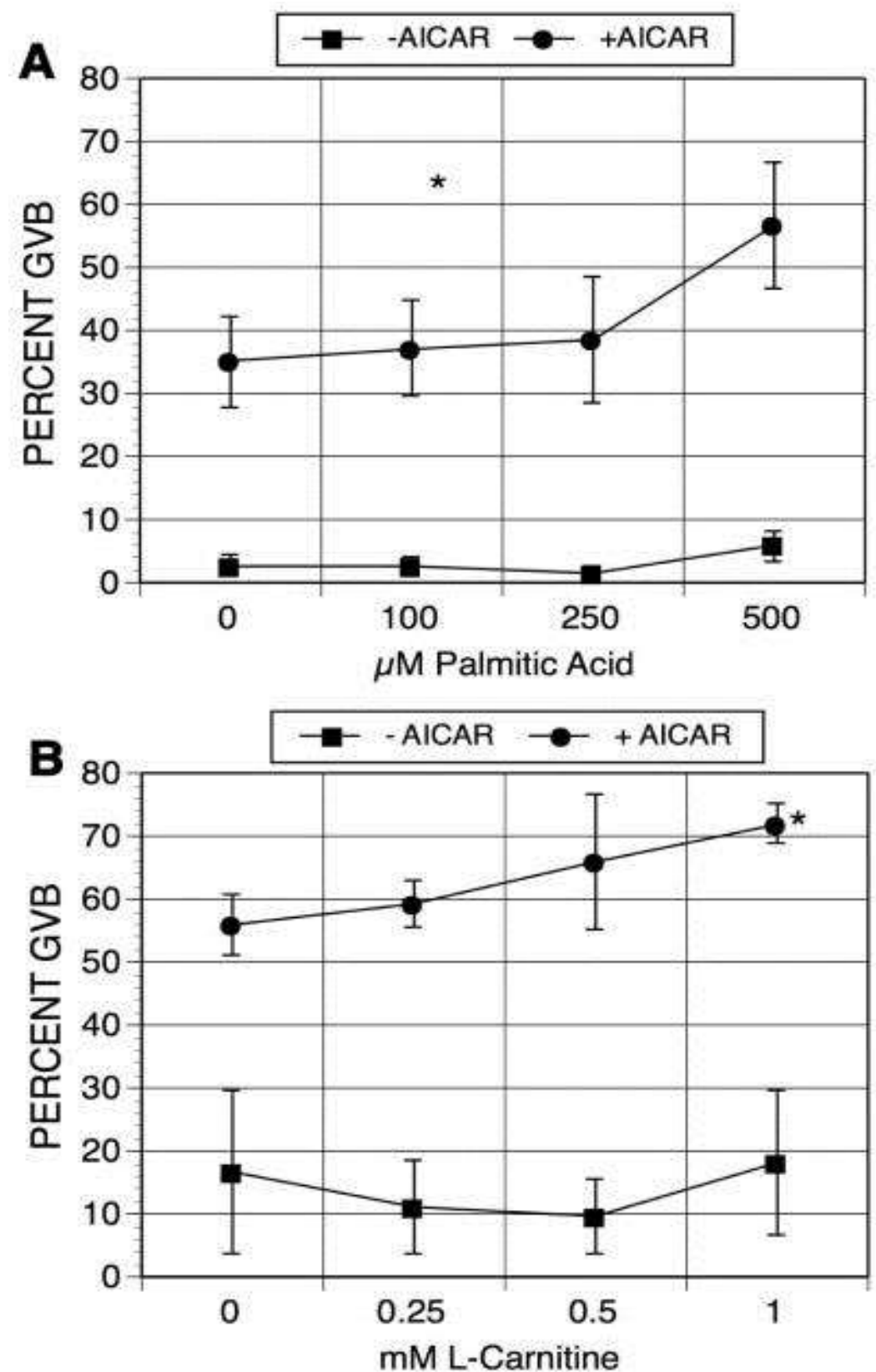

Molecular Reproduction and development, Vol. 76, No. 9 (September 2009): pg. 844-853. DOI. This article is (C) Wiley and permission has been granted for this version to appear in e-Publications@Marquette. Wiley does not grant permission for this article to be further copied/distributed or hosted elsewhere without the express permission from Wiley. 
NOT THE PUBLISHED VERSION; this is the author's final, peer-reviewed manuscript. The published version may be accessed by following the link in the citation at the bottom of the page.

Figure 6 Effect of palmitic acid and carnitine on meiotic induction in DO. DO were cultured $4 \mathrm{~h}$ in medium containing $300 \mu \mathrm{M}$ dbcAMP plus or minus $125 \mu \mathrm{M}$ AICAR and were exposed to increasing concentrations of palmitic acid (A) or carnitine (B). An asterisk denotes a significant difference from controls.

If C75 stimulates oocyte maturation by activating fatty acid oxidation, then blocking this pathway should prevent C75-induced maturation. CEO were therefore cultured $18 \mathrm{~h}$ in dbcAMP or hypoxanthine plus $100 \mu \mathrm{M} \mathrm{C75}$ or $10 \mu \mathrm{M}$ cerulenin and treated with etomoxir. Since intial experiments determined that etomoxir was more potent in dbcAMP-supplemented medium than in hypoxanthinesupplemented medium, 100 and $250 \mu \mathrm{m}$ etomoxir was used in the dbcAMP and hypoxanthine experiments, respectively. Under both inhibitory conditions, C75 again stimulated a high percentage of oocytes to resume maturation when meiotic arrest was maintained by either hypoxanthine (Fig. 5B) or dbcAMP (Fig. 5C), and this stimulation was eliminated by treatment with etomoxir. Cerulenin also stimulated maturation, but in each case to a lesser extent, and etomoxir failed to block maturation in either group. These data suggest that the meiosisinducing effect of $\mathrm{C} 75$, but not cerulenin, is mediated by activation of fatty acid oxidation.

\section{Inhibition of AMPK fails to block C75-induced maturation}

If C75 acts downstream of AMPK to stimulate meiotic resumption, then blocking AMPK activity should have little effect on C75-induced maturation. To test this idea, dbcAMP-arrested CEO stimulated with C75 or AICAR were treated with the AMPK inhibitor, compound C (Zhou et al, 2001), during overnight cultures. AICAR increased the maturation frequency from $20 \%$ to $99 \%$, and the response to AICAR was reduced to $28 \%$ GVB by compound C (Fig. 5D). C75 also stimulated most of the oocytes to resume maturation ( $90 \%$ GVB), but compound C had no significant impact on GVB in C75treated oocytes, which indicates that C75 is not acting through AMPK.

\section{Palmitic acid and carnitine promote meiotic induction induced by AICAR}

To assess whether fatty acids have a positive effect on meiotic maturation, DO maintained in meiotic arrest with dbcAMP in the

Molecular Reproduction and development, Vol. 76, No. 9 (September 2009): pg. 844-853. DOI. This article is @ Wiley and permission has been granted for this version to appear in e-Publications@Marquette. Wiley does not grant permission for this article to be further copied/distributed or hosted elsewhere without the express permission from Wiley. 
presence or absence of AICAR were exposed to increasing concentrations of palmitic acid during $4 \mathrm{~h}$ cultures. A concentration of $125 \mu \mathrm{m}$ AICAR was chosen to produce a modest meiosis-inducing effect; in this way, the potential stimulatory effects of palmitic acid could be tested under conditions of presumptive fatty acid oxidation stimulation. These results are shown in Fig. 6A. Only negligible oocyte maturation was observed in dbcAMP alone ( $3 \%$ GVB), and no further change was seen with the addition of palmitic acid. Treatment with AICAR increased the maturation percentage to $35 \%$, and palmitic acid at the highest dose tested $(500 \mu \mathrm{M})$ significantly increased the meiotic response to $57 \%$.

Since fatty acyl CoA uptake by mitochondria requires the replacement of the $\mathrm{Co} A$ group with carnitine, we tested the effects of carnitine on AICAR-induced maturation of dbcAMP-arrested DO during $4 \mathrm{~h}$ cultures. Little maturation occurred when oocytes were cultured in $300 \mu \mathrm{M}$ dbcAMP, and carnitine alone was unable to stimulate meiotic resumption (Fig. 6B). The addition of $125 \mu \mathrm{M}$ AICAR increased the maturation percentage by $38 \%$, and this was further increased in dose-dependent fashion by carnitine, such that a significant stimulation of maturation ( $54 \%$ GVB) occurred at $2 \mathrm{mM}$. Thus, like the results with palmitic acid, stimulation of maturation by carnitine required treatment with AICAR.

\section{Meiotic induction by carnitine derivatives of fatty acids}

If fatty acids have a positive influence on oocyte maturation following the addition of carnitine to acyl derivatives and their subsequent oxidation, then carnitine derivatives of fatty acids would be able to bypass the need for CPT1 (see Fig. 1) and may exhibit a meiosis-inducing effect. We therefore tested the effects of the C16 carnitine derivative, palmitoylcarnitine, on meiotically arrested oocytes. For these experiments, oocytes were maintained in meiotic arrest with hypoxanthine, since initial experiments using dbcAMP resulted in inconsistent data. CEO or DO were cultured 17-18 h in medium containing $4 \mathrm{mM}$ hypoxanthine in the presence of increasing concentrations of palmitoylcarnitine. As shown in Fig. 7A, meiotic resumption was induced in dose-dependent fashion by palmitoylcarnitine in both CEO and DO. However, an increase in oocyte death was observed at the two higher doses of palmitoyl carnitine, with $24.5 \%$ of DO dead at $75 \mu \mathrm{M}$ and $29.6 \%$ and $51.5 \%$ of CEO and

Molecular Reproduction and development, Vol. 76, No. 9 (September 2009): pg. 844-853. DOI. This article is @ Wiley and permission has been granted for this version to appear in e-Publications@Marquette. Wiley does not grant permission for this article to be further copied/distributed or hosted elsewhere without the express permission from Wiley. 
DO, respectively, dead at $100 \mu \mathrm{M}$. Less than $10 \%$ of the oocytes failed to survive culture in all other groups.
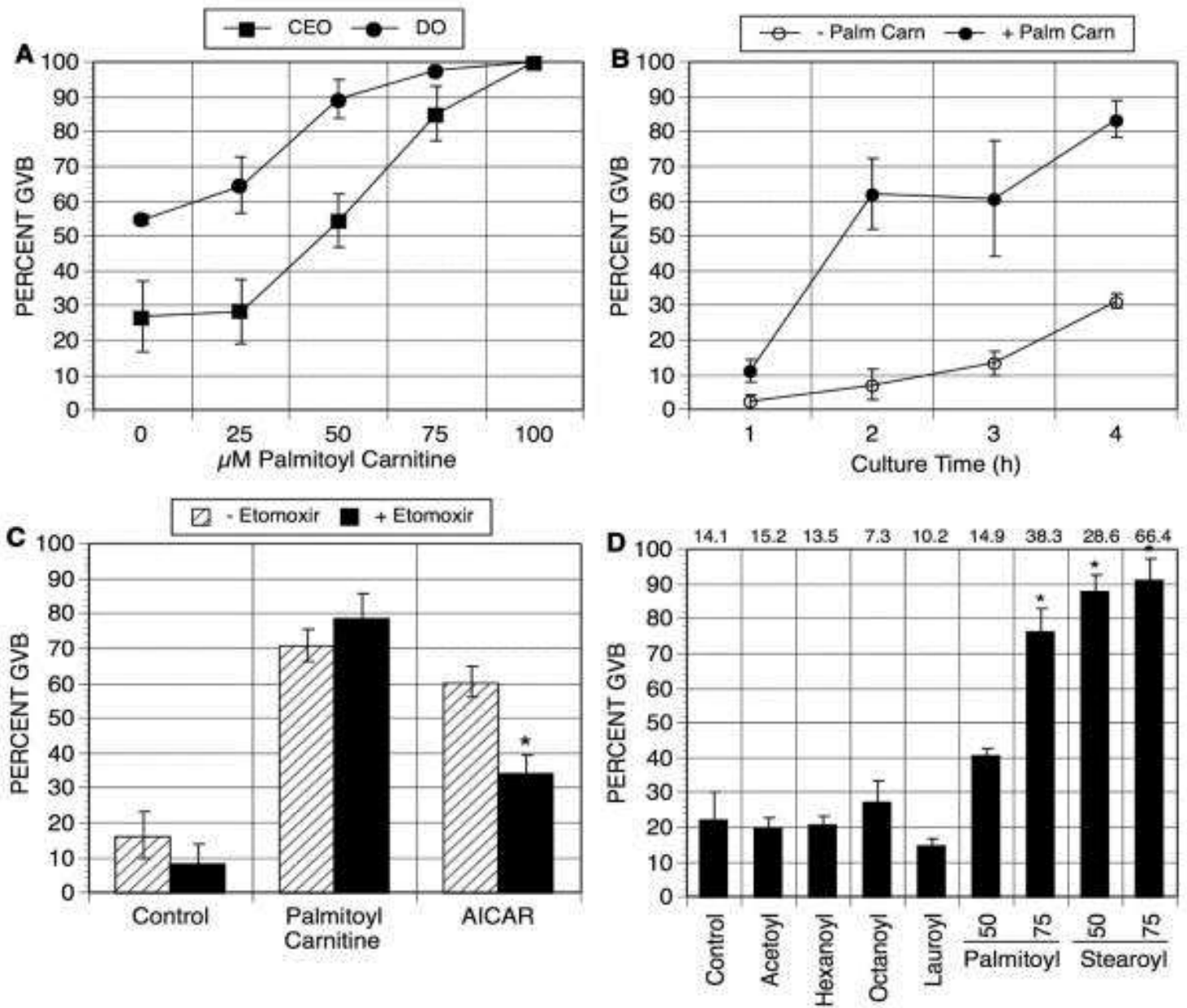

Figure 7 Meiotic induction by carnitine derivatives of fatty acids. A, Dose response effect of C75. CEO and DO were cultured $17-18 \mathrm{~h}$ in medium containing $4 \mathrm{mM}$ hypoxanthine plus increasing concentrations of palmitoyl carnitine. B, Time course of meiotic induction. DO were cultured $1-4 \mathrm{~h}$ in medium containing hypoxanthine in the presence or absence of $75 \mu \mathrm{M}$ palmitoyl carnitine. C, effect of etomoxir on meiotic induction. DO were cultured $4 \mathrm{~h}$ in $4 \mathrm{mM}$ hypoxanthine plus $75 \mu \mathrm{M}$ palmitoyl carnitine or $250 \mu \mathrm{M}$ AICAR, plus or minus $250 \mu \mathrm{M}$ etomoxir. An asterisk denotes a significant difference from the -etomoxir group. D, Effect of fatty acid chain length on meiotic induction. DO were cultured $4 \mathrm{~h}$ in $4 \mathrm{mM}$ hypoxanthine plus fatty acyl carnitines at a concentration of $75 \mu \mathrm{M}$. Palmitoyl and stearoyl carnitines were also added at $50 \mu \mathrm{M}$. Numbers at the top of the bar denote the mean percentage of dead oocytes for each treatment. An asterisk denotes a significant difference from the control group.

Molecular Reproduction and development, Vol. 76, No. 9 (September 2009): pg. 844-853. DOI. This article is (C Wiley and permission has been granted for this version to appear in e-Publications@Marquette. Wiley does not grant permission for this article to be further copied/distributed or hosted elsewhere without the express permission from Wiley. 
The kinetics of palmitoylcarnitine-induced maturation were next evaluated. DO were cultured $1,2,3$ or $4 \mathrm{~h}$ in medium containing $4 \mathrm{mM}$ hypoxanthine in the presence or absence of $75 \mu \mathrm{M}$ palmitoyl carnitine. Remarkably, significant stimulation of meiotic resumption occurred within $2 \mathrm{~h}$ (an increase from $7.2 \%$ to $62 \%$ GVB), and this number was increased to $83.6 \%$ after $4 \mathrm{~h}$, although the control maturation frequency had also increased at a comparable rate to $31.2 \%$ (Fig. 7B).

Since palmitoyl carnitine is produced by the activity of CPT1 (see Fig. 1), it should therefore be able to bypass this target of etomoxir inhibition. To test this, DO were cultured $4 \mathrm{~h}$ in $4 \mathrm{mM}$ hypoxanthine plus $75 \mu \mathrm{M}$ palmitoyl carnitine plus or minus $250 \mu \mathrm{M}$ etomoxir. As a positive control, oocytes were also stimulated with AICAR. While etomoxir significantly reduced AICAR-induced maturation (by $26.2 \%$ ), it had no effect on palmitoyl carnitine-stimulated maturation (Fig. 7C), consistent with the idea that palmitoyl CoA acts downstream of CPT1 (Fig. 1).

To determine the effect of fatty acid chain length on meiotic induction, carnitine derivatives of different saturated fatty acids were tested. DO were cultured $4 \mathrm{~h}$ in $4 \mathrm{mM}$ hypoxanthine plus fatty acyl carnitines at a concentration of $75 \mu \mathrm{M}$. Palmitoyl and stearoyl carnitines were also added at $50 \mu \mathrm{M}$ due to the increased number of dead oocytes at the higher concentration when compared to the other groups. As shown in Fig. 7D, the acetyl (C2), hexanoyl (C6), octanoyl (C8) and lauroyl (C12) derivatives had no effect on oocyte maturation, but palmitoyl (C16) and stearoyl (C18) carnitine each stimulated a significant number of oocytes to resume maturation. A dose-

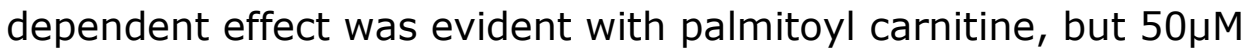
stearoyl carnitine was as effective as $75 \mu \mathrm{m}$ in triggering GVB. It is also important to note that two-thirds (66.4\%) of the oocytes exposed to $75 \mu \mathrm{M}$ stearoyl carnitine died within $4 \mathrm{~h}$ compared to $28.6 \%$ exposed to $50 \mu \mathrm{m}$. Consistent with earlier experiments, $38.2 \%$ of oocytes treated with $75 \mu \mathrm{m}$ palmitoyl carnitine died after $4 \mathrm{~h}$ of culture. These results show that long chain, but not short chain, fatty acyl carnitine derivatives are stimulatory to oocyte maturation; in addition, this effect was associated with increased oocyte death.

Molecular Reproduction and development, Vol. 76, No. 9 (September 2009): pg. 844-853. DOI. This article is (C Wiley and permission has been granted for this version to appear in e-Publications@Marquette. Wiley does not grant permission for this article to be further copied/distributed or hosted elsewhere without the express permission from Wiley. 
NOT THE PUBLISHED VERSION; this is the author's final, peer-reviewed manuscript. The published version may be accessed by following the link in the citation at the bottom of the page.

\section{Inhibitors of fatty acid oxidation enzymes block palmitoylcarnitine-induced maturation}

Replacement of the carnitine moiety with CoA within the mitochondrion converts fatty acids into substrates for the first enzyme of FAO, acyl CoA dehydrogenase (see Fig. 1B). If $\beta$-oxidation of palmitoyl carnitine is required for its meiosis-inducing effect, then inhibition of acyl CoA dehyrogenase should block its action. Thus, DO were cultured $4 \mathrm{~h}$ in hypoxanthine-supplemented medium containing $75 \mu \mathrm{m}$ palmitoylcarnitine plus increasing concentrations of the acyl CoA dehydrogenase inhibitor, mercaptoacetate (MA; Bauche et al, 1982). While palmitoylcarnitine increased the percentage of hypoxanthine-arrested oocytes undergoing GVB from $25 \%$ to $88 \%$, this effect was eliminated in dose-dependent fashion by MA (Fig.8A). It is important to note that $1.5 \mathrm{mM}$ MA completely suppressed meiotic induction without increasing the number of dead oocytes, although oocyte death was increased at the higher dose of $2 \mathrm{mM}$. Moreover, when at the end of culture germinal vesicle-stage oocytes that were exposed to the two highest doses of MA were transferred to control, inhibitor-free medium and cultured overnight, 84\% resumed maturation and more than half of these formed polar bodies.

Molecular Reproduction and development, Vol. 76, No. 9 (September 2009): pg. 844-853. DOI. This article is @ Wiley and permission has been granted for this version to appear in e-Publications@Marquette. Wiley does not grant permission for this article to be further copied/distributed or hosted elsewhere without the express permission from Wiley. 


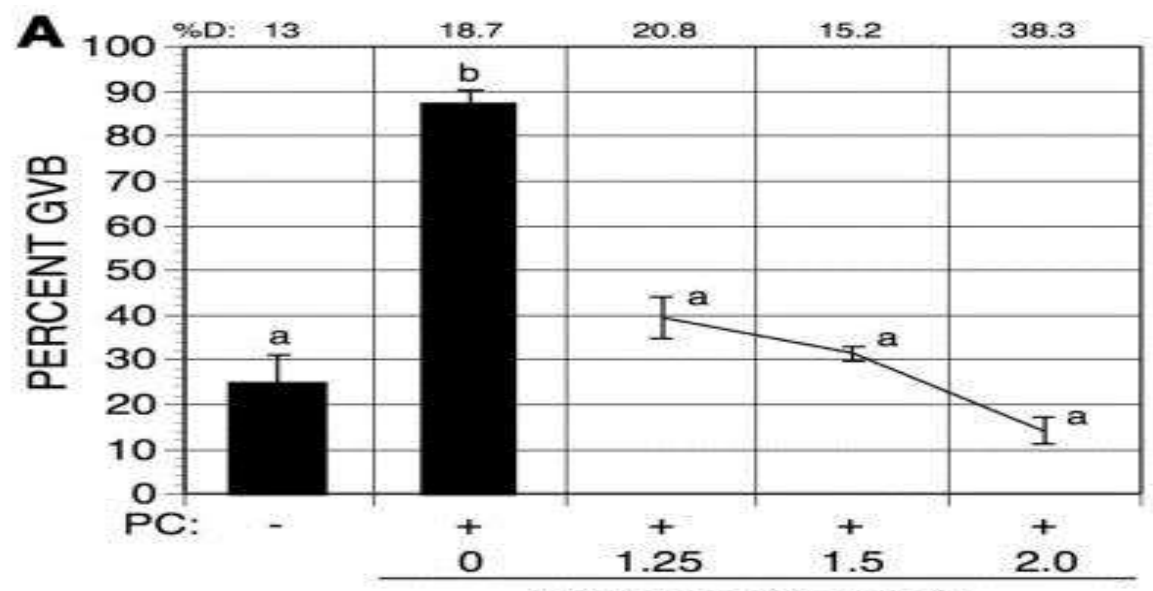

mM Mercaptoacetate

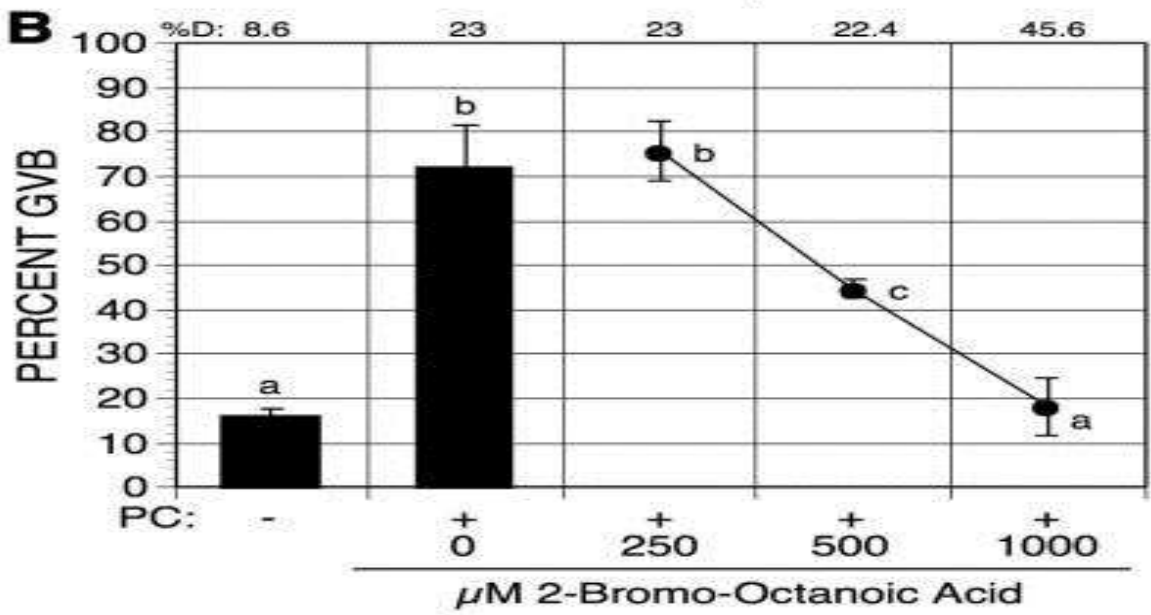

Figure 8 Effect of fatty acid oxidation inhibitors on meiotic induction by palmitoyl carnitine. DO were cultured $0.5 \mathrm{~h}$ in $4 \mathrm{mM}$ hypoxanthine plus or minus increasing concentrations of mercaptoacetate (MA, A) or 8-bromo-octanoic acid (B) and then 75 $\mu \mathrm{m}$ palmitoyl carnitine was added to each tube. Cultures were continued for $4 \mathrm{~h}$ before oocytes were assessed for GVB. Numbers at the top of the bar denote the mean percentage of dead oocytes for each treatment. Groups with no common letter are significantly different.

To further assess the dependency of palmitoylcarnitine-induced maturation on fatty acid oxidation, the experiment was repeated with 2-bromo-octanoic acid, an inhibitor of thiolase, the downstream and rate-limiting enzyme of fatty acid $\beta$-oxidation (Rupp et al, 2002). As shown in Fig. 8B, 2-bromo-octanoic acid dose-dependently suppressed palmitoylcarnitine-induced maturation in DO. The effects of this agent were also reversible, as $93 \%$ of the GV-stage oocytes exposed to the two highest concentrations resumed maturation and more than half formed polar bodies. The reversibility of the inhibition by both agents 
NOT THE PUBLISHED VERSION; this is the author's final, peer-reviewed manuscript. The published version may be accessed by following the link in the citation at the bottom of the page.

suggests that their effect on maturation was not due to a nonspecific toxic effect on the oocyte.

\section{DISCUSSION}

In this study we have presented evidence that increased fatty acid oxidation within the mouse oocyte is associated with induction of meiotic maturation. C75, an activator of fatty acid oxidation, stimulated meiotic resumption in arrested mouse oocytes, while two separate inhibitors of CPT1 (etomoxir and malonyl CoA) prevented the meiotic induction brought about by the AMPK activator, AICAR. The effectiveness of C75 in both DO and CEO suggests that the oocyte is the target for its action. Cerulenin, an inhibitor of fatty acid synthesis, also stimulated meiotic resumption, but only in CEO, and it was less potent, exhibited much slower kinetics, and was insensitive to etomoxir inhibition. Palmitic acid and carnitine augmented the meiotic induction brought about by AICAR in DO, but had no effect in the absence of AICAR, suggesting their positive action required activation of fatty acid oxidation within the oocyte. Carnitine derivatives of long chain fatty acids were effective inducers of meiotic maturation in both CEO and DO, with rapid kinetics of meiotic resumption, and this action was insensitive to CPT1 inhibition but sensitive to inhibitors of fatty acid oxidation. These data support the idea that AMPK-induced meiotic resumption in mouse oocytes in vitro is dependent on activation of the fatty acid oxidation pathway.

Since a prominent response of cells to AMPK activation is an increase in fatty acid oxidation (Hardie, 2003), we examined the possibility that AMPK-induced meiotic resumption is associated with an increase in the activity of this metabolic pathway. Initial experiments involved the use of two inhibitors of CPT1, malonyl CoA and etomoxir. Malonyl CoA is the product of ACC activity and thus is an intermediate within the fatty acid synthetic pathway, while etomoxir is a pharmacological inhibitor. Both agents significantly suppressed AICARinduced maturation in dbcAMP-arrested DO, suggesting that the transport of fatty acids into the mitochondria for $\beta$-oxidation helps drive meiotic induction. This response was not unique to dbcAMParrested oocytes, since etomoxir was also inhibitory to meiotic induction when hypoxanthine or milrinone was used to maintain meiotic arrest. Also, the response to etomoxir was unique for ligandstimulated maturation, since spontaneous maturation was not affected, though this inhibitor augmented the extent of meiotic arrest in oocytes cultured in dbcAMP alone. While the reason for this response is not known, it may explain the better inhibitory potency of

Molecular Reproduction and development, Vol. 76, No. 9 (September 2009): pg. 844-853. DOI. This article is @ Wiley and permission has been granted for this version to appear in e-Publications@Marquette. Wiley does not grant permission for this article to be further copied/distributed or hosted elsewhere without the express permission from Wiley. 
this agent in stimulated oocytes maintained in meiotic arrest with this cyclic nucleotide analog.

Since inhibitors of CPT1 were able to block meiotic induction, it followed that activators of this pathway might have the opposite effect-ie, stimulation of meiotic resumption. To test this idea, we used C75, an established inhibitor of fatty acid synthesis that was recently shown to stimulate fatty acid oxidation via activation of CPT1, the enzyme that replaces the CoA on fatty acyl CoA with carnitine and promotes entry of fatty acids into the mitochondrion for subsequent oxidation (Thupari et al, 2002). C75 proved to be a potent inducer of meiotic maturation in both CEO and DO and under a variety of meiosis-inhibiting conditions. Thus, the oocyte is the site of C75 action, which is consistent with the results of the inhibitor experiments. In addition, as predicted, C75 acts downstream of AMPK, since the AMPK inhibitor, compound C, blocked AICAR-induced maturation but was unable to block C75-induced maturation.

However, because $\mathrm{C75}$ is also an inhibitor of fatty acid synthesis, it was important to test the effects of another FAS inhibitor, cerulenin, on meiotically arrested oocytes. While cerulenin also exhibited meiosis-inducing ability, it was less potent, slower acting, and completely ineffective in DO. Moreover, etomoxir was able to block C75-induced, but not cerulenin-induced, maturation of CEO, indicating that these agents act by separate mechanisms to trigger GVB. It is not clear how cerulenin stimulates meiotic maturation, but it is apparently an indirect effect, mediated through the cumulus cells. One possible interpretation is that interfering with fatty acid synthesis in the cumulus cells somehow leads to a positive action on the oocyte, but further experimentation is required before definitive conclusions can be drawn.

To determine if precursors of fatty acyl carnitine could augment meiotic induction, dose response experiments were carried out with palmitic acid and carnitine in AICAR-stimulated DO that were maintained in meiotic arrest with dbcAMP. While neither agent had any effect in the absence of AICAR, under modest stimulatory conditions both palmitic acid and carnitine augmented the meiosis-inducing effect of AICAR. These results demonstrate that precursors of fatty acyl carnitine can promote meiotic maturation, but also suggest that this response requires CPT1 stimulation.

In a previous study, we utilized palmitoylcarnitine to examine the potential role of protein kinase $C$ (PKC) in mouse oocyte meiotic regulation (Downs et al, 2001), because palmitoylcarnitine has been

Molecular Reproduction and development, Vol. 76, No. 9 (September 2009): pg. 844-853. DOI. This article is (C Wiley and permission has been granted for this version to appear in e-Publications@Marquette. Wiley does not grant permission for this article to be further copied/distributed or hosted elsewhere without the express permission from Wiley. 
shown to be a PKC antagonist (Katoh et al, 1981; Wise and Kuo, 1983). In that study, the meiosis-inducing action of palmitoylcarnitine was attributed to a PKC-suppressing activity within the oocyte, since its effects were mimicked by other PKC inhibitors (Downs et al, 2001). The action of palmitoylcarnitine on oocytes was revisited in the present study with the idea that it is situated downstream of CPT1 and could enter mitochondria, undergo oxidation and trigger GVB. Thus, the effects of fatty acyl carnitine derivatives on hypoxanthine-maintained meiotic arrest were tested in CEO and DO. Higher molecular weight (C16, C18), but not lower molecular weight (C2-C12), derivatives were effective inducers of meiotic maturation, and significant stimulation of GVB was observed in DO within only $2 \mathrm{~h}$ of culture. Such a rapid induction of meiosis, plus the fact that palmitoylcarnitine action was insensitive to etomoxir but sensitive to fatty acid oxidation inhibitors, provides further evidence for the participation of fatty acid oxidation in oocyte maturation. In addition, the meiosis-inducing action of the larger carnitine derivatives implicates the involvement of long-, and perhaps very long-, chain acyl-CoA dehydrogenase in meiotic resumption. However, it cannot be determined from these data whether the effect of palmitoylcarnitine is related to an interaction with PKC.

Ratchford et al (2007) recently reported that acyl CoA dehydrogenase activity in oocytes from diabetic mice was impaired when compared to controls, in association with a reduction in meiotic resumption. Moreover, treatment of these oocytes with AICAR stimulated AMPK and restored the maturation deficit. Interestingly, a deficiency of long-chain acyl-CoA dehydrogenase in mice results in reduced litter sizes (Cox et al, 2001), and this may be explained, at least in part, by an inability of preimplantation embryos to form a blastocoel (Berger and Wood, 2004). This same pathway is also important for oocyte maturation in domestic species (Sturmey and Leese, 2003; Ferguson and Leese, 2006), and treatment of pig oocytes during in vitro maturation with MA or the CPT1 inhibitor, methyl palmoxirate, compromised embryo development following in vitro fertilization (Sturmey et al, 2006).

The results of this study provide compelling evidence that fatty acid oxidation is an important regulator of oocyte meiotic maturation in mice and is influenced by the level of AMPK activity. While this conclusion was reached using pharmacological manipulators of metabolism, it is also supported by results of preliminary experiments using more physiological activators of maturation. The involvement of fatty acid metabolism in oocyte maturation is somewhat surprising considering that oocytes can undergo maturation with simple

Molecular Reproduction and development, Vol. 76, No. 9 (September 2009): pg. 844-853. DOI. This article is @ Wiley and permission has been granted for this version to appear in e-Publications@Marquette. Wiley does not grant permission for this article to be further copied/distributed or hosted elsewhere without the express permission from Wiley. 
carbohydrates such as pyruvate as the sole energy source (Biggers et al, 1967; Eppig, 1976). It is for this reason that considerable effort has been expended in the past examining the importance of carbohydrate metabolism during oocyte maturation, but little is known about how carbohydrate and fatty acid metabolic pathways interact throughout oocyte and embryo development. It will be important in future studies to examine the extent of fatty acid oxidation activity in the oocyte under different conditions of meiotic regulation, including energy supplementation, and how this relates to meiotic status.

\section{MATERIALS AND METHODS}

\section{Oocyte isolation and culture conditions}

Animals were raised in the research colony of the principal investigator (SMD). All experiments were carried out with prior approval of the Marquette University Institutional Animal care and Use Committee. C57BL/6]xSJL/J FI mice, 19-23 days old, were used for all experiments. Mice were primed with 5 IU equine choronic gonadotropin and killed $48 \mathrm{~h}$ later by cervical dislocation. Ovaries were removed and placed in the culture medium, and cumulus cell-enclosed oocytes (CEO) were obtained by puncturing large antral follicles with sterile needles. Denuded oocytes were prepared by repeated pipetting with a Pasteur pipette or by passage through mouth-operated small bore pipets. Tubes were gassed with a humidified mixture of $5 \% \mathrm{CO}_{2}$, $5 \% \mathrm{O}_{2}$ and $90 \% \mathrm{~N}_{2}$ and placed in a water bath at $37^{\circ} \mathrm{C}$ for the duration of culture.

The culture medium used was Eagle's minimum essential medium with Earle's salts (GIBCO/Invitrogen; Carlsbad, CA), supplemented with $0.23 \mathrm{mM}$ pyruvate, penicillin, streptomycin sulfate and $3 \mathrm{mg} / \mathrm{ml}$ crystallized lyophilized bovine serum albumin (ICN ImmunoBiologicals, Lisle, IL) and buffered with $26 \mathrm{mM}$ bicarbonate.

\section{Cumulus Expansion}

Cumulus expansion was assayed following a 17-18 $\mathrm{h}$ incubation in MEM supplemented with $5 \%$ fetal bovine serum. Expansion was scored according to a subjective scale ranging from 0 (no expansion) to +4 (complete expansion), and a cumulus expansion index was calculated as previously described (Fagbohun and Downs, 1990).

Molecular Reproduction and development, Vol. 76, No. 9 (September 2009): pg. 844-853. DOI. This article is (C Wiley and permission has been granted for this version to appear in e-Publications@Marquette. Wiley does not grant permission for this article to be further copied/distributed or hosted elsewhere without the express permission from Wiley. 
NOT THE PUBLISHED VERSION; this is the author's final, peer-reviewed manuscript. The published version may be accessed by following the link in the citation at the bottom of the page.

\section{Chemicals}

AICAR was purchased from Toronto research Chemicals, Inc. (North York, Ontario), and C75 was supplied by Alexis Biochemicals (Axxora LLC, San Diego, CA). Sigma Chemical Co (St Louis, MO) was the source for dibutyryl cyclic AMP, hypoxanthine, malonyl CoA, palmitic acid, L-carnitine, guanosine, milrinone, cerulenin, etomoxir, and all fatty acyl carnitine derivatives. Highly purified ovine FSH was obtained from the National Hormone and Peptide Program (NHPP), NIDDK, and Dr. A.F. Parlow.

\section{Statistical Analysis}

Oocyte maturation experiments were repeated at least 3 times with at least 25 oocytes per group per experiment. Data are reported as mean percentage GVB \pm SEM. Maturation frequencies were analyzed statistically by ANOVA followed by Duncan's multiple range test. For all statistical analyses, a $\mathrm{P}$ value less than 0.05 was considered significant.

\section{REFERENCES}

1. Bauche F, Sabourault D, Giudicelli Y, Nordmann J, Nordmann R. Effects of 2-mercaptoacetate in isolated liver mitochondria in vitro. Competitive inhibition of 3-hydroxybutyrate dehydrogenase and depression of the beta-oxidation pathway. Biochem J. 1982;206:53-59.

2. Biggers JD, Whittingham DG, Donahue RP. The pattern of energy metabolism in the mouse oocyte and zygote. Proc Natl Acad Sci USA. $1967 ; 58: 560-567$.

3. Berger PS, Wood PA. Disrupted blastocoele formation reveals a critical developmental role for long-chain acyl-CoA dehydrogenase. Mol Gen Metab. 2004;82:266-272.

4. Carling D, Clarke PR, Zammit VA, Hardie DG. Purification and characterization of the AMP-activated protein kinase: copurification of acetyl-CoA carboxylase and 3-hydroxy-3-methyglutaryl-CoA reductase kinase activities. Eur J Biochem. 1989;186:129-136.

5. Carling D, Fryer L, Woods A, Daniel T, Jarvie S, Whitrow H. Bypassing the glucose/fatty acid cycle: AMP-activated protein kinase. Biochem Soc Trans. 2003;31:1157-1160.

Molecular Reproduction and development, Vol. 76, No. 9 (September 2009): pg. 844-853. DOI. This article is @ Wiley and permission has been granted for this version to appear in e-Publications@Marquette. Wiley does not grant permission for this article to be further copied/distributed or hosted elsewhere without the express permission from Wiley. 
6. Chen J, Hudson E, Chi MM, Chang AS, Moley KH, Hardie DG, Downs SM. AMPK regulation of mouse oocyte meiotic resumption in vitro. Dev Biol. 2006;291:227-238.

7. Conti M, Hsieh M, Park J-Y, Su Y-Q. Role of the epidermal growth factor network in ovarian follicles. Mol Endocrinology. 2006;20:715-723.

8. Cox KB, Hamm DA, Millington DS, Matern D, Vockley J, Rinaldo P, Pinkert CA, Rhead WJ, Lindsey JR, Wood PA. Gestational, pathologic and biochemical differences between very long-chain acyl-CoA dehydrogenase deficiency and long-chain acyl-CoA dehydrogenase deficiency in the mouse. Hum Mol Gen. 2001;10:2069-2-77.

9. Davies SP, Carling D, Munday MR, Hardie DG. Diurnal rhythm of phosphorylation of rat liver acetyl-CoA carboxylase by the AMPactivated protein kinase, demonstrated using freeze-clamping. Effects of high fat diets. Eur J Biochem. 1992;203:615-623.

10. Declercq PE, Falck JR, Kuwajima M, Tyminski H, Foster DW, McGarry JD. Characterization of the mitochondrial carnitine palmitoyltransferase enzyme system. I. Use of inhibitors. J Biol Chem. 1987;262:98129821.

11. Downs SM, Chen J. EGF-like peptides mediate FSH-induced matureation of cumulus cell-enclosed mouse oocytes. Mol Reprod Dev. 2008; 75:105-114.

12. Downs SM, Cottom J, Hunzicker-Dunn M. Protein kinase $C$ and meiotic regulation in isolated mouse oocytes. Mol Reprod Dev. 2001;58:101115.]

13. Downs SM, Hudson ER, Hardie DG. A potential role for AMP-activated protein kinase in meiotic induction in mouse oocytes. Dev Biol. $2002 ; 245: 200-212$.

14. Eppig JJ. Analysis of mouse oogenesis in vitro. Oocyte isolation and utilization of exogenous energy sources by growing oocytes. J Exp Zool. 1976;198:375-382.

15. Fagbohun F, Downs SM. Maturation of the mouse oocyte-cumulus cell complex: stimulation by lectins. Biol Reprod. 1990;42:413-423.

16. Ferguson $\mathrm{EM}$, Leese $\mathrm{HJ}$. A potential role for triglyceride as an energy source during bovine oocyte maturation and early embryo development. Mol Reprod Dev. 2006;73:1195-1201.

17. Hardie DG. Minireview: the AMP-activated protein kinase cascade: the key sensor of cellular energy status. Endocrinology. 2003;144:5179-5183.

Molecular Reproduction and development, Vol. 76, No. 9 (September 2009): pg. 844-853. DOI. This article is @ Wiley and permission has been granted for this version to appear in e-Publications@Marquette. Wiley does not grant permission for this article to be further copied/distributed or hosted elsewhere without the express permission from Wiley. 
18. Katoh N, Wrenn RW, Wise BC, Shoji M, Kuo JF. Substrate proteins for calmodulin-sensitive and phospholipid-sensitive $\mathrm{Ca}^{2+}$-dependent protein kinases in heart, and inhibition of their phosphorylation by palmitoylcarnitine. Proc Natl Acad Sci USA. 1981;78:4813-4817.

19. Kawaguchi A, Tomoda H, Nozoe S, Omura S, Okuda S. Mechanism of action of cerulenin on fatty acid synthetase. Effect of cerulenin on iodoacetamide-induced malonyl-CoA decarboxylase activity. J Biochem. 1982;92:7-12.

20. Kuhajda FP, Pizer ES, Li JN, Mani NS, Frehywot GL, Townsend CA. Synthesis and antitumor activity of an inhibitor of fatty acid synthase. Proc Natl Acad Sci. 2000;97:3450-3454.

21. Landree LE, Hanlon AL, Strong DW, Rumbaugh G, Miller IA, Thupari JN, Connolly EC, Huganir RL, Richardson C, Witters LA, Kuhajda FP, Ronnett GV. C75, a fatty acid synthase inhibitor, modulates AMPactivated protein kinase to alter neuronal energy metabolism. J Biol Chem. 2004;279:3817-3827.

22. LaRosa C, Downs SM. Stress stimulates AMP-activated protein kinase and meiotic resumption in mouse oocytes. Biol Reprod. 2006;74:585-592.

23. LaRosa C, Downs SM. Meiotic induction by heat stress in mouse oocytes: involvement of AMP-activated protein kinase and MAPK family members. Biol Reprod. 2007;76:476-486.

24. Loftus TM, Jaworsky DE, Frehywot GL, Townsend CA, Ronnet GV, Lane MD, Kuhajda FP. Reduced food intake and body weight in mice treated with fatty acid synthease inhibitors. Science. 2000;288:2379-2381.

25. McGarry JD, Brown NF. The mitochondrial carnitine palmitoyltransferase system. From concept to molecular analysis. Eur J Biochem. $1997 ; 244: 1-14$.

26.Omura S. The antibiotic cerulenin, a novel tool for biochemistry as an inhibitor of fatty acid synthesis. Bacteriol Rev. 1976;40:681-697.

27. Park H, Kaushik VK, Constant S, Prentki M, Przybytkowski E, Ruderman NB, Saha AK. Coordinate regulation of malonyl-CoA decarboxylase, snglycerol-3-phosphate acyltransferase, and acetyl-CoA carboxylase by AMP-activated protein kinase in rat tissues in response to exercise.l. J Biol Chem. 2002a;277:32571-32577.

28. Park SH, Gammon SR, Knippers JD, Paulsen SR, Rubink DS, Winder WW. Phosphorylation-activity relationships of AMPK and acetyl-CoA carboxylase in muscle. J Appl Physiol. 2002b;92:2475-2482.

Molecular Reproduction and development, Vol. 76, No. 9 (September 2009): pg. 844-853. DOI. This article is (C Wiley and permission has been granted for this version to appear in e-Publications@Marquette. Wiley does not grant permission for this article to be further copied/distributed or hosted elsewhere without the express permission from Wiley. 
NOT THE PUBLISHED VERSION; this is the author's final, peer-reviewed manuscript. The published version may be accessed by following the link in the citation at the bottom of the page.

29. Ratchford AM, Chang AS, Chi MM-Y, Sheridan R, Moley KH. Maternal diabetes adversely affects AMP-activated protein kinase activity and cellular metabolism in murine oocytes. Am J Physiol Endocrinol Metab. 2007;293:E1198-E1206.

30. Ruderman NB, Saha AK, Kraegen EW. Minireview: malonyl CoA, AMPactivated protein kinase, and adiposity. Endocrinology. 2003; 144:5166-5171.

31. Rupp H, Zarain-Herzberg A, Maisch B. The use of partial fatty acid oxidation inhibitors for metabolic therapy of angina pectoris and heart failure. Herz. 2002;27:621-636.

32. Sturmey RG, Leese HJ. Energy metabolism in pig oocytes and early embryos. Reprod. 2003;126:197-204

33. Sturmey RG, O'Toole PJ, Leese HJ. Fluorescence resonance energy transfer analysis of mitochondrial:lipid association in the porcine oocyte. Reprod. 2006;132:829-837.

34. Thupari JN, Landree LE, Ronnett GV, Kuhajda FP. C75 increases peripheral energy utilitzation and fatty acid oxidation in diet-induced obesity. Proc Natl Acad Sci. 2002;99:9498-9502.

35. Tong L. Acetly-coenzyme A carboxylase: crucial metabolic enzyme and attractive target for drug discovery. Cell Mol Life Sci. 2005;62:17841803.

36. Wise BC, Kuo JF. Modes of inhibition by acylcarnitines, adriamycin and trifluoroperazine of cardiac phospholipid-sensitive calcium-dependent protein kinase. Biochem Pharm. 1983;32:1259-1265.

37. Wolfgang MJ, Lane MD. The role of hypothalamic malonyl-CoA in energy homeostasis. J Biol Chem. 2006;281:37265-37269.

38. Yang N, Kays JS, Skillman TR, Burris L, Seng TW, Hammond C. C75 [4methylene-2-octyl-5-oxo-tetrahydro-furan-3-carboxylic acid] activates carnitine palmitoyltransferase- 1 in isolated mitochondria and intact cells without displacement of bound malonyl CoA. J Pharm Exp Ther. $2005 ; 312: 127-133$.

39. Zhou G, Myers R, Li Y, Chen Y, Shen X, Fenyk-Melody J, Wu M, Ventre J, Doebber T, Fujii N, Musi N, Hirshman MF, Goodyear LJ, Moller DE. Role of AMP-activated protein kinase mechanism of metformin action. J Clin Invest. $2001 ; 108: 1167-1174$.

Molecular Reproduction and development, Vol. 76, No. 9 (September 2009): pg. 844-853. DOI. This article is @ Wiley and permission has been granted for this version to appear in e-Publications@Marquette. Wiley does not grant permission for this article to be further copied/distributed or hosted elsewhere without the express permission from Wiley. 
NOT THE PUBLISHED VERSION; this is the author's final, peer-reviewed manuscript. The published version may be accessed by following the link in the citation at the bottom of the page.

\section{About the Authors}

Stephen M. Downs: Telephone: (414) 288-1698

Email: stephen.downs@marquette.edu

Molecular Reproduction and development, Vol. 76, No. 9 (September 2009): pg. 844-853. DOI. This article is (C Wiley and permission has been granted for this version to appear in e-Publications@Marquette. Wiley does not grant permission for this article to be further copied/distributed or hosted elsewhere without the express permission from Wiley. 